\title{
The Impact of Environmental Corporate Social Responsibility on Enterprise Performance-— Implications for Sustainable Development Strategy
}

\author{
Ao Xiangyuan ${ }^{1}$, Ong Tzesan ${ }^{2}$ \\ ${ }^{1,2}$ Universiti Putra Malaysia, 43400 UPM Serdang Selangor Darul Ehsan, MALAYSIA
}

\begin{abstract}
This paper selected 119 listed companies from 2008 to 2018 in mainland China as samples, aiming to further explore the different impacts of environmental corporate social responsibility (ECSR) on corporate performance in the long and short term, and explore the mediating role of corporate green marketing performance. The results show that CSR has a significant impact on the return on assets and enterprise value in the short term. In the long-term, the adoption of green marketing innovation has a positive impact on enterprise performance. In general, the results of this paper are of great significance for managers and external investors to implement decisions. In addition, the research results can help enterprises improve their environmental responsibility and green innovation in order to improve their competitiveness.
\end{abstract}

\section{Introduction}

Since the reform and opening up, the Chinese economy has achieved. remarkable results. From 1978 to 2018, China's GDP grew by $9.4 \%$ annually, surpassing Japan in 2010 and causing China to become the second largest economy in the world (Gan, Yang \& Liang, 2020). According to Asian Development Bank (ADB, 2001), among 41 cities ranked by particular air pollution, eight of the worst 10 are in China. Russo (1997) believes that enterprises that pay attention to pollution control and take the initiative to assume environmental responsibilities can provide enterprises with two kinds of intangible resources. With the expansion of research methods, the debate turned into the economic consequences of enterprises taking social responsibilities (Holman and Singer, 1990), that is to take into account the enterprise environmental performance. According to the Chinese Environmental Protection Department, more than $80 \%$ of pollution is caused by the production and operation of enterprises (Wei et al., 2017). Enterprises should actively fulfil their social responsibility to pollution prevention and control and carry out environmental governance because they continuously request and benefit from environmental resources and benefits that allow them to increase production and operation activities (Wei, Zhou, 2020).

This paper mainly discusses the impact of environmental social responsibility policy on corporate performance in the long and short term, as well as the mediating role of corporate green marketing innovation performance. The results of this study will help enterprises to make different decisions about their interests. First, the management of an enterprise can improve its competitiveness more effectively by implementing different environmental protection strategies. In addition, external information receivers of an enterprise can make effective investment decisions based on short-term environmental CSR information disclosure. Moreover, this paper positively affirms the research conclusions of previous scholars, and carries out further empirical analysis on this basis, which will also help future researchers to study the relationship between corporate environmental responsibility and corporate performance.

\section{Literature Review and Hypothesis Development}

\subsection{Environmental corporate social responsibility (ECSR) and Stakeholder theory}

As an integral part of CSR, environmental corporate social responsibility (ECSR) plays a crucial role in firms in regard to their interactions with the natural environment (Kim, Park, \& Ryu, 2017). Turker (2009) defined ECSR refers to the activities aimed at environmental protection for community development and sustainability. Stakeholder theory provides an appropriate perspective for the study of ECSR. The main motivation for enterprises to implement ECSR comes from the pressure of various stakeholders (Wu, Liang, \& Zhang, 2020). Recently, ECSR has been increasingly gaining recognition as one way to integrate different interests of their external stakeholders, which can help 
them be deeply embedded in the networks among stakeholders (Steurer, Langer, Konrad, \& Martinuzzi, 2005). A growing number of studies have discussed what drives firms to engage in environmental CSR and how it affects their performance (Barnett \& Salomon, 2012). ECSR is to satisfy the demands of different stakeholders, which allowed them to access and capitalize on tangible and intangible resources $(\mathrm{Wu}$, Liang, \& Zhang,2020). According to the concept of sustainable development, firm's profit and environmental protection can be parallel and compatible; profit maximization is no longer the only goal pursued by the firm (Li, Liao and Albitar,2020). Therefore, ECSR is likely to become a source of competitive advantage (Lloret, 2016). In fact, environmental corporate social responsibility requires firms to achieve a balance between profit and environmental protection in their products, production processes, and production behaviors, through the improvement of technology applications to achieve green innovation of products $(\mathrm{Li}$, Liao, \& Albitar, 2020).

Based on the above literature review and theoretical basis, the first hypothesis is proposed

H1: There is a significant relationship between ECSR and enterprise performance (EP)

\subsection{Green marketing innovation performance (GMT) and Enterprises performance (EP)}

Kitsikopoulos et al. (2018) point out that enterprises' green innovation activities, as a measure of environmental behavior, are also driven by stakeholders' attitudes. Chen et al. (2006) and Weng et al. (2015) found that green innovation can improve corporate performance and competitive advantage. Makower (2009) emphasizes that enterprises need to incorporate green marketing strategies to achieve sustainable competitive advantages. Green marketing innovation performance is a part of green marketing strategy (Mukonza \& Swarts, 2019), while Chang (2011) and Chen (2008) believe that the development of green innovation is a win-win solution to solve the conflict between economic development and environmental protection. The pressure from government stakeholders and the motivation of enterprises' environmental responsibility led enterprises to actively participate in green marketing innovation (Yen, 2018). Green marketing plans are considered as a bridge linking corporate environmental ethics to corporate performance (Papadas, Avlonitis, Carrigan and Piha, 2018).

Based on the above viewpoints, this study proposes Hypothesis 2 \& 3:

$\mathrm{H} 2$ : ECSR is positively related to enterprise green marketing innovation performance.

H3: Enterprise green marketing innovation moderates the relationship between ECSR and enterprise performance.

\subsection{Research framework}

Based on the literature review and hypothesis development above, this study proposes the following research hypothesis in Figure 2.

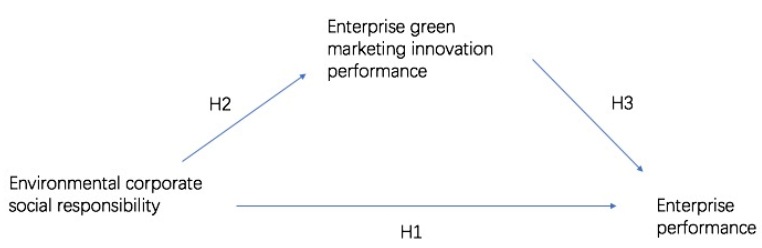

Fig. 1. Conceptual framework

\section{Research Design}

\subsection{Data collection and sample}

The initial sample of this study selected the data of Ashare enterprises in China's stock market from 2008 to 2018. During this period, the enterprise disclosed information related to the environmental responsibility of the enterprise, and the enterprise disclosed information related to environmental protection subsidies and financial data. Although many corporates lacked information samples related to environmental expenditure and environmental responsibility, 119 effective samples were finally selected. The data sources for this study are from the CSMAR database, HEXUN and the company's official website.

\subsection{Measurement of variables}

\subsubsection{Dependent Variable}

The dependent variable used in this study is enterprise performance (EP). Enterprise performance is generally estimated using financial and market indicators (Wan and Liu, 2013; Tu and. Zheng, 2018). Return on assets (ROA) of an enterprise are used to compare the impact of the enterprise performance before and after their used. Value creation is usually measured in terms of ROA. The "Tobin's Q" coefficient was first defined by economist James Tobin's in 1969 as the ratio of an enterprise's market value to the replacement cost of assets. When Tobin's Q is high, the relative market value of an enterprise is high and investment activities can be carried out. When Tobin's Q is low, an enterprise's relative market value is low and investment activities should be reduced. Therefore, Tobin's and ROA would be considered to measure enterprise performance.

\subsubsection{Independent Variable}

The independent variable is Environmental corporate social responsibility (ECSR). In previous studies, the environmental dimension of corporate social responsibility was generally used to score environmental corporate social responsibility. For example, Pan et. al (2019) used HEXUN data to score ECSR in multiple 
dimensions. In this study, according to Chen et. Al (2020) and Patten (2005), (corporate investment in environmental protection/ total assets) $* 100$ is adopted as the proxy variable for corporate social responsibility in environment.

\subsubsection{Mediator}

The mediator of this study adopts enterprise green marketing innovation performance. The concept of green marketing innovation performance refers to that enterprises promote social development and human health in the process of improving environmental conditions, meeting consumer needs and obtaining competitive market advantages (Hao, Fan, Long, \& Pan, 2019; Khanna, Isik, and Zilberman, 2002). Therefore, according to the above scholars' research, the measurement of green marketing innovation performance in this study is enterprise environmental protection subsidy/ (operation revenue + non-operation revenue).

\subsection{Model construction}

In this study, one independent variable ECSR, one mediator GMT and two dependent variables Tobin Q and ROA were used. Based on the hypothesis development in the second section, the research model of this paper is as follows.

Model 1 aims to explore the impact of ECSR on enterprise performance.

\section{$\mathrm{EP}=($ Model 1)}

Similarly, Model 2 discuss the influence of ECSR on green marketing innovation performance of enterprises.

GMT $=($ Model 2$)$

Model 3 is to investigate the moderating role of green marketing innovation performance between ECSR and enterprise performance.

$\mathrm{EP}=($ Model 3$)$

On the basis of the above model, Li, Liao, \& Albitar (2020) studies the mediating effect of enterprise environmental responsibility, enterprise value and enterprise innovation, which provides a valuable perspective to explore the long-term and short-term differences between ECSR participation in enterprise value. Therefore, this paper divides the time span of an enterprise into 2008-2018 as a long-term period and 2014-2018 as a short-term period.

\section{EMPIRICAL RESULTS}

\subsection{Short-term results}

Table 1. Correlations in short-term.

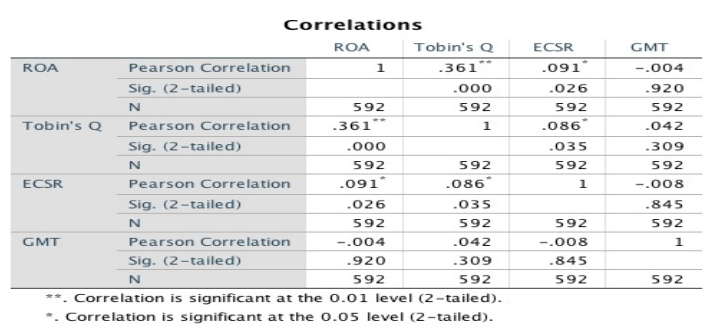

The results of test model 1 in a short-term are shown in Table 1, which shows the correlations of relationship between ECSR, EP and GMT. In this short-term model, it is worth noting that the P-values of both GMT and EP variables are greater than 0.05 , which makes the adoption of green marketing innovation strategy have no significant impact on enterprise performance in the short term. However, in terms of environmental corporate social responsibility, P- value of ROA and Tobin's Q less than 0.05 in the short term, which means that the performance of enterprises has a significant improvement in ROA and Tobin's Q. Therefore, the following study will focus on the analysis of these two variables.

\subsubsection{ROA and enterprise environmental responsibility}

Table 2. ANOVA Table.

ANOVA $^{\mathrm{a}}$

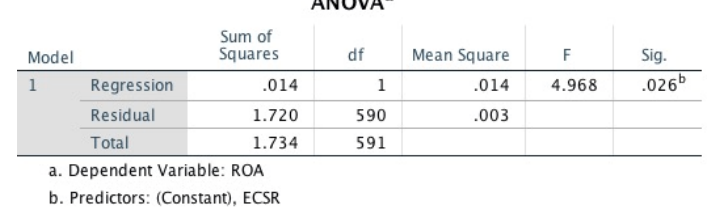

The table above shows the effect of adopting environmental CSR on ROA in the short term. The Pvalue equal to 0.026 less that 0.05 , which means the adoption of ECSR policy has a significant impact on the return on assets in the 2014-2018.

Table 3. Correlation Coefficient Table.

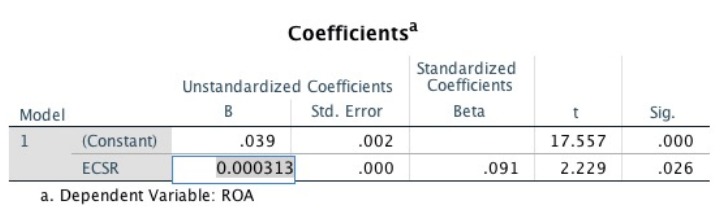

According to the results of the correlation Table3, there is a statistical significance between ECSR and the ROA of the enterprise. The regression equation is as follows

$$
\mathrm{ROA}=0.000313 * \mathrm{ECSR}+0.039 \quad \text { (Equation 1) }
$$

The Equation 1 shows that the implementation of the environmental social responsibility policy has a positive 
impact on the return on assets of enterprises in the short term.

\subsubsection{Tobin's $Q$ and ECSR}

Table 4. ANOVA Table.

\begin{tabular}{|c|c|c|c|c|c|c|}
\hline \multicolumn{7}{|c|}{ ANOVA $^{a}$} \\
\hline Model & & $\begin{array}{l}\text { Sum of } \\
\text { Squares }\end{array}$ & df & Mean Square & $\mathrm{F}$ & Sig. \\
\hline \multirow[t]{3}{*}{1} & Regression & 7.566 & 1 & 7.566 & 4.446 & $.035^{\mathrm{b}}$ \\
\hline & Residual & 1004.100 & 590 & 1.702 & & \\
\hline & Total & 1011.666 & 591 & & & \\
\hline
\end{tabular}

The results of Table 4 show that the P-value of Tobin's Q equal 0.035 is also less than 0.05 . This result means that the environmental responsibility policy of enterprises in the short term has a significant impact on Tobin's Q value.

Table 5. Correlation Table.

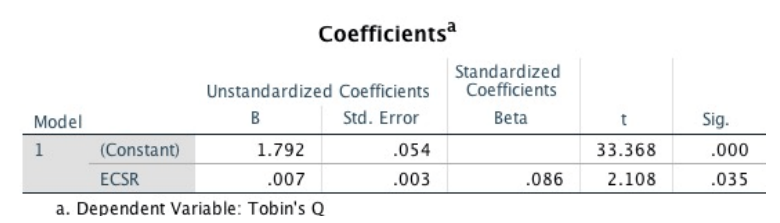

According to the correlation coefficient table, the relationship between Tobin's Q and environmental corporate social responsibility is as follows: Tobin's $\mathrm{Q}=$ $0.007 *$ ECSR + 1.792 (Equation 2). It can be concluded that the value of Tobin's Q is positively correlated with environmental enterprise policies in the short term.

\subsubsection{The Mediating Effect of Enterprise Green Marketing Innovation Performance}

Table 6. Summary of Model 3.

\begin{tabular}{|c|c|}
\hline & Sig. \\
\hline ROA & 0.084 \\
\hline Tobin's Q & 0.064 \\
\hline
\end{tabular}

The table above shows that in the short term, there is no significant influence between the green marketing innovation performance and various variables of enterprise performance. Therefore, this article tests the relationship between mediation variables and independent variables.

Table 7. Model Summary.

\begin{tabular}{|c|c|c|c|c|c|c|c|c|c|}
\hline \multirow[b]{3}{*}{ Model } & \multicolumn{9}{|c|}{ Model Summary } \\
\hline & \multirow[b]{2}{*}{$R$} & \multirow[b]{2}{*}{ R Square } & \multirow[b]{2}{*}{$\begin{array}{l}\text { Adjusted R } \\
\text { Sqquare }\end{array}$} & \multirow[b]{2}{*}{$\begin{array}{l}\text { Stdd Error of } \\
\text { the Estimate }\end{array}$} & \multicolumn{5}{|c|}{ Change Satitsics } \\
\hline & & & & & $\begin{array}{l}\text { RS Square } \\
\text { Change }\end{array}$ & FChange & dfil & diz & Sig. F Change \\
\hline 1 & $.008^{\mathrm{a}}$ & .000 & -.002 & .033523776 & .000 & .038 & 1 & 590 & .845 \\
\hline
\end{tabular}

From the above results, in the short term, the green marketing innovation strategy of enterprises has no intermediary effect. This does not mean rejecting the hypothesis before, this study will be further explored in the long-term.

In the short-term, there is a positive correlation between ECSR and corporate return on investment and Tobin's Q value in corporate performance. However, there is no mediating effect on the green marketing performance of enterprises according to the data of the last 5 years.

\subsection{The results for long-term}

Long-term data were selected from 119 sample enterprises from 2008 to 2018.

Table 8. Correlations in long-term.

\begin{tabular}{|c|c|c|c|c|c|}
\hline \multicolumn{6}{|c|}{ Correlations } \\
\hline & & ROA & Tobin's Q & ECSR & GMT \\
\hline \multirow[t]{3}{*}{ ROA } & Pearson Correlation & 1 & $.497^{* *}$ & .031 & $.081^{\star *}$ \\
\hline & Sig. (2-tailed) & & .000 & .256 & .003 \\
\hline & $\mathrm{N}$ & 1309 & 1309 & 1309 & 1309 \\
\hline \multirow[t]{3}{*}{ Tobin's Q } & Pearson Correlation & $.497^{* *}$ & 1 & .052 & .053 \\
\hline & Sig. (2-tailed) & .000 & & .059 & .054 \\
\hline & $\mathrm{N}$ & 1309 & 1309 & 1309 & 1309 \\
\hline \multirow[t]{3}{*}{ ECSR } & Pearson Correlation & .031 & .052 & 1 & -.005 \\
\hline & Sig. (2-tailed) & .256 & .059 & & .868 \\
\hline & $\mathrm{N}$ & 1309 & 1309 & 1309 & 1309 \\
\hline \multirow[t]{3}{*}{ GMT } & Pearson Correlation & $.081^{* *}$ & .053 & -.005 & 1 \\
\hline & Sig. (2-tailed) & .003 & .054 & .868 & \\
\hline & $\mathrm{N}$ & 1309 & 1309 & 1309 & 1309 \\
\hline
\end{tabular}

From the long-term correlation coefficient, it is not difficult to conclude that, contrarily, after the implementation of ECSR, there is no significant impact on enterprise performance (P-value are all greater than 0.05). In the aspect of green marketing innovation performance, only the return on investment and green marketing innovation performance have significant impact.

\subsubsection{ROA and GMT in long-term}

Table 9. ANOVA table.

\begin{tabular}{|c|c|c|c|c|c|c|}
\hline \multicolumn{7}{|c|}{ ANOVA $^{\mathrm{a}}$} \\
\hline Model & & $\begin{array}{l}\text { Sum of } \\
\text { Squares }\end{array}$ & df & Mean Square & $\mathrm{F}$ & Sig. \\
\hline \multirow[t]{3}{*}{1} & Regression & .033 & 1 & .033 & 8.678 & $.003^{b}$ \\
\hline & Residual & 4.900 & 1307 & .004 & & \\
\hline & Total & 4.933 & 1308 & & & \\
\hline
\end{tabular}

The above table shows the results of ANOVA analysis. At $95 \%$ confidence interval, $P$ value of 0.03 is smaller than 0.05 , which means that the green marketing performance of enterprises has significant influence on the return on investment of enterprises in a long-term. 
Table 10. Coefficients.

\begin{tabular}{|c|c|c|c|c|c|c|}
\hline \multicolumn{7}{|c|}{ Coefficients $^{\mathrm{a}}$} \\
\hline \multirow[b]{2}{*}{ Model } & & \multicolumn{2}{|c|}{ Unstandardized Coefficients } & \multirow{2}{*}{$\begin{array}{c}\text { Standardized } \\
\text { Coefficients } \\
\text { Beta }\end{array}$} & \multirow[b]{2}{*}{$\mathrm{t}$} & \multirow[b]{2}{*}{ Sig. } \\
\hline & & B & Std. Error & & & \\
\hline \multirow[t]{2}{*}{1} & (Constant) & .051 & .002 & & 30.160 & .000 \\
\hline & GMT & .044 & .015 & .081 & 2.946 & .003 \\
\hline
\end{tabular}

The correlation coefficient table reveals that under longterm conditions, the slope of ROA and GMT is 0.044 and greater than 0 , so the return on assets of enterprises is positively correlated with green marketing innovation performance. The regression equation can be concluded that $\mathrm{ROA}=0.044 * \mathrm{GMT}+0.051$.

In long-term, since ECSR has no significant effect on enterprise performance, there is no mediating effect. Therefore, this paper will stop analyzing the mediating effect.

In summary, during the five years from 2014 to 2018 , the adoption of ECSR policy has a positive impact on the return on assets and Tobin's $Q$ value of enterprises. In addition, the green marketing innovation performance of enterprises is not significant and does not have a mediating effect. In the long-term, the enterprise's environmental protection policy has no significant impact on the enterprise's performance. On the contrary, the enterprise's green marketing innovation has a significant positive impact on the enterprise's return on assets. Although, again, there is no mediating effect.

\section{Discussion}

The conclusion of the results concludes that there are many different influencing factors in the actual business operation, resulting in the difference of results. More and more companies are actively taking on environmental corporate social responsibility and trying to use it as a competitive advantage. According to theoretical results, in the short term, the increase of environmental capital expenditure has a positive impact on the return on assets of enterprises. In addition, the results show that in the short term, the higher the proportion of environmental capital expenditure in total assets, the higher the relative market value of the enterprise, which explains that in the short term, the ECSR policy of the enterprise is helpful to improve the competitive advantage of the enterprise.

In the long-term, the cost of corporate environmental responsibility has no significant impact on corporate performance from 2008 to 2018. However, in terms of the innovation performance of green marketing in the market, the higher the proportion of environmental protection subsidy in the sum of operation revenue and non-operation revenue of Chinese enterprises, the higher the return on assets of enterprises. However, Tobin's Q have no significant effect on enterprises. This indicates that in the long-term, enterprises should properly pay attention to green marketing innovation, which will help companies better adjust long-term environment and green innovation strategies.

\section{CONCLUSION AND LIMITATIONS}

In conclusion, this research tests the relationship between environmental corporate social responsibility, enterprise performance and corporate green marketing innovation performance respectively in the long and short term. The implementation of environmental corporate social responsibility will have a positive impact on the performance of enterprises in the short term, while the green marketing innovation performance will have a positive impact on their performance in the long term. Furthermore, the research results of this study can provide reference for enterprise decision makers, government and investors. For the decision makers of the enterprise, the appropriate choice of corporate environmental strategy is conducive to improving the financial performance and competitive advantage of the enterprise. For government departments, the improvement of long-term environmental protection subsidies is beneficial to the performance of local enterprises, thus encouraging enterprises to disclose more ECSR information. In addition, investors can pay more attention to the disclosure of environmental responsibility information of enterprises in the past five years. The larger the proportion of enterprises' investment in environmental protection, the higher the competitiveness of enterprises and the easier it is for investors to make benefits.

Based on the suggestions given by $\mathrm{Li}$, Liao, \& Albitar in 2020, this study explores differences of environmental CSR engagement on corporate value between the long-term and short-term. However, the sample only focuses on listed companies in China and only considers the green innovation performance of enterprises. Therefore, future studies can further study different emerging countries and regions or consider further mediating variables.

\section{References}

1. Barnett, M. L., \& Salomon, R. M. (2012). Does it pay to be really good? Addressing the shape of the relationship between social and financial performance. Strategic Management Journal, 33(11), 1304- 1320. https://doi.org/10.1002/smj.1980.

2. Bansal, P., \& Roth, K. (2000). Why companies go g reen: A model of ecological responsiveness. Acade my of Management Journal, 43(4), 717- 736. https:/ /doi.org/10.2307/1556363.

3. Freeman, J. (1997) 'Socially irresponsible and illega 1 behavior and shareholder wealth: A meta-analysis of event studies', Business and Society, 36(3), pp. 2 21-249. doi: 10.1177/000765039703600302.

4. Holman, W. R., New, J. R., \& Singer, D. (1990). Th e impact of corporate social responsiveness on share holder wealth. In L. E. Preston (Ed.), Corporation an $\mathrm{d}$ society research: Studies in theory and measureme nt. Greenwich, CT: JAI Press

5. Kassinis, G., \& Vafeas, N. (2002). Corporate boards and outside stakeholders. as determinants of enviro 
nmental litigation. Strategic Management Journal, 2 3(5), 399-415. https://doi.org/10.1002/smj.230

6. Kim, H., Park, K., \& Ryu, D. (2017). Corporate envi ronmental responsibility: A legal origins perspective. Journal of Business Ethics, 140(3), 381-402. https: //doi.org/10.1007/s10551-015-2641-1.

7. Miras-Rodríguez, M. M., Carrasco-Gallego, A., and Escobar-Pérez, B. (2015) Has the CSR engagement of electrical companies had an effect on their perfor mance? A

8. closer look at the environment. Bus. Strat. Env., 24: 819-835. doi: 10.1002/bse.1848.

9. Zhu, Q, Zou, F, Zhang, P. The role of innovation for performance improvement through corporate social responsibility practices among small and medium-si zed suppliers in China. Corp Soc Resp Env Ma. 201 9; 26: 341-350. https://doi.org/10.1002/csr.1686

10. Hao, Y, Fan, C, Long, Y, Pan, J. The role of returne e executives in improving green innovation perform ance of Chinese manufacturing enterprises: Implicat ions for sustainable development strategy. Bus Strat Env. 2019; 28: 804- 818. https://doi.org/10.1002/bs e. 2282

11. Russo, M. V. V. and Fouts, P. A. A. (1997) 'A resou rce-based perspective on corporate environmental pe rformance and profitability', Academy of Managem ent Journal. Academy of Management, 40(3), pp. 53 4-559. doi: 10.2307/257052.

12. Pan, $X$, Sinha, $P$, Chen, $X$. Corporate social responsi bility and eco-innovation: The triple bottom line per spective. Corp Soc Responsib Environ Manag. 2020; $1-15$.

13. https://doi.org/10.1002/csr.2043

14. $\mathrm{Wu}, \mathrm{W}$, Liang, Z, Zhang, Q. Effects of corporate en vironmental responsibility strength and concern on $i$ nnovation performance: The moderating role of firm visibility. Corp Soc Resp Env Ma. 2020; 27: 14871497. https://doi.org/10.1002/csr.1902

15. Chang, C.-H. (2011). The influence of corporate env ironmental ethics on competitive advantage: The me diation role of green innovation. Journal of Business Ethics, 104(3), 361-370.

16. Chen, Y. S. (2008). The driver of green innovation a nd green image - green core competence. Journal of Business Ethics, 81(3), 531-543.

17. Papadas, K. K., Avlonitis, G. J., Carrigan, M., \& Pih a, L. (2018). The interplay of strategic and internal $g$ reen marketing orientation on competitive advantage. Journal of Business Research. In press, https://doi.o $\mathrm{rg} / 10.1016 /$ j.jbusres.2018.07.009

18. Khanna, M., Isik, M., \& Zilberman, D. (2002). Costeffectiveness of alternative green payment policies $\mathrm{f}$ or conservation technology adoption with heterogen eous land quality. Agricultural Economics, 27(2), 15 7-174. https://doi.org/10.1016/S0169-5150(02)0003 4-8

19. Li, Z, Liao, G, Albitar, K. Does corporate environm ental responsibility engagement affect firm value? $\mathrm{T}$ he mediating role of corporate innovation. Bus Strat Env. 2020; 29: 1045- 1055. https://doi.org/10.1002/ bse. 2416

20. Makower, J. (2009). Strategies for the green econom $\mathrm{y}$ : Opportunities and challenges in the new world of business. New York: McGraw-Hill.

21. Yen, Y. X. (2018). Buyer-supplier collaboration in green practices: The driving effects from stakeholde rs. Business Strategy and the Environment, 27(8), 16 66-1678. https://doi.org/10.1002/bse.2231

22. Porter, M. E., \& van der Linde, C. (1995). Green an d competitive: Ending the stalemate. Harvard Busin ess Review, 73(5), 120-134.

23. Han, M, Lin, H, Wang, J, Wang, Y, Jiang, W. Turni ng corporate environmental ethics into firm perform ance: The role of green marketing programs. Bus Str at Env. 2019; 28: 929- 938. https://doi.org/10.1002/ bse. 2290 